\title{
A Pilot Study of Nutritive Profile and Consumer's Acceptability of Frozen Saba Crispy
}

\author{
Norrina Din'1, Bustamam Bonari2, Nurul Imtiaz Abd Gani3 ${ }^{3}$, Cunlin $\mathrm{Li}^{4}$ \\ ${ }^{1}$ Faculty of Hotel and Tourism Management, Universiti Teknologi MARA Cawangan Pulau Pinang Kampus Permatang Pauh, \\ 13500 Permatang Pauh, Pulau Pinang, Malaysia \\ ${ }^{2}$ Tourism and Hospitality Department, Politeknik Tuanku Sirajuddin, Perlis \\ ${ }^{3}$ School of Languages, Civilisation and Philosophy, Universiti Utara Malaysia \\ ${ }^{4}$ School of Management, North Minzu University, No.204,Wenchang North Street,Xixia District,Yinchuan,Ningxia,P.R.China \\ 750001
}

1norrina.din@uitm.edu.my, 2busptss@gmail.com, 3nurulimtiaz@uum.edu.my, ${ }^{4 b i t l c l @ 163 . c o m ~}$ Tel +6042823677

\begin{abstract}
Banana is a topical fruit consumed worldwide. Since bananas lifecycle is short, prolonging its' shelf life is necessary to cater for the increasing demand of globalization. This study aims to evaluate frozen bananas' quality proportional to nutritional profile and the products' acceptability as traditional readyto-eat food. A pilot study with 30 respondents looking at the attributions between Saba Crispy and raw Saba using a 5-point Likert scale yielded 50\% agreeing to texture, taste, and flavor of Saba Crispy and $66.67 \%$ for colors. Hence, the product's color and texture influence the customer's acceptance and should be marketed with new varieties.
\end{abstract}

Keywords: Saba Banana, Malays, Frozen and Nutritive

eISSN: 2398-4287@ 2021. The Authors. Published for AMER ABRA cE-Bs by e-International Publishing House, Ltd., UK. This is an open access article under the CC BYNC-ND license (http://creativecommons.org/licenses/by-nc-nd/4.0/). Peer-review under responsibility of AMER (Association of Malaysian Environment-Behaviour Researchers), ABRA (Association of Behavioural Researchers on Asians/Africans/Arabians) and cE-Bs (Centre for Environment-Behaviour Studies), Faculty of Architecture, Planning \& Surveying, Universiti Teknologi MARA, Malaysia.

DOI: https://doi.org/10.21834/ebpj.v6i17.2893

\subsection{Introduction}

Banana, one of the six fruits of Paradise mentioned in the Quran: And [banana] trees layered [with fruit] "Amid thornless lote-trees, and banana-trees (with fruits), one above another, and extended shade, and water flowing constantly, and abundant fruit, neither intercepted nor forbidden" (Holy Quran Al Waqiah 56:29). In this verse, the Almighty Allah revealed that the banana is one such blessing fruit and far more perfect than any fruits we can imagine in this world. It is a fruit that exists to the whole world of people with a taste and smells that we cannot invent.

The word 'banana' refers to the fruit of evergreen, giant herb, and exclusively subtropical belonging to the genus Musa from the family of Musaceae (Lassoudière, 2007). Banana is an elongated tropical fruit with a creamy texture, pleasing aroma, and sweet taste (Ploetz, Kepler, Daniells, \& Nelson, 2007). Banana is considered the leading food in many countries (Singh, Singh, Kaur \& Singh, 2016; Nelson, Ploetz \& Kepler, 2006). Since this fruit is highly demanded, it was ranked as the fourth most essential food globally after other foods, namely rice, wheat, and maize. It is also consumed as the primary food resource and an alternative to rice and corn (Reginio,

eISSN: 2398-42870 2021. The Authors. Published for AMER ABRA cE-Bs by e-International Publishing House, Ltd., UK. This is an open access article under the CC BYNC-ND license (http://creativecommons.org/licenses/by-nc-nd/4.0/). Peer-review under responsibility of AMER (Association of Malaysian Environment-Behaviour Researchers), ABRA (Association of Behavioural Researchers on Asians/Africans/Arabians) and CE-Bs (Centre for Environment-Behaviour Studies), Faculty of Architecture, Planning \& Surveying, Universiti Teknologi MARA, Malaysia. DOI: https://doi.org/10.21834/ebpj.v6i17.2893 
Ketnawa \& Ogawa, 2020). However, banana has a short life span (Ferreira \& Freitas, 2019) that needed further investigation to prolong the shelf life for food security due to weather uncertainty like El Nino.

Bananas have been widely grown and inexpensive in over 130 countries in Southeast Asia, including Malaysia, and it has an excellent potential to be exported abroad (Reginio, Ketnawa \& Ogawa, 2020). There are approximately 300 types of bananas grown worldwide (Singh et al., 2016). An edible banana was grouped based on the chromosome sets existent and the proportion of genomes of M. acuminata (A) and M. balbisiana (B). The hybridization of M. acuminata and M. balbisiana will produce a plantain, a banana used for cooking (Hapsari \& Lestari, 2016; Singh et al., 2016). The characteristic of banana and plantain are almost identical, depending on the amount of starch and sugar in the fruits (Hapsari \& Lestari, 2016; Singh et al., 2016). Although their purpose is different (Singh et al., 2016), both are called bananas (Hapsari \& Lestari, 2016).

Today, seedless bananas from cross-breeding of M. acuminata and M. balbisiana have been prevalent in our norm of living (Singh et al., 2016). In Malaysia, banana comes from the Musa Accuminata and Musa Balbisiana family. Banana can be eaten and cooked as chips, salad, main dishes, and dessert. Besides, the whole fruits can be mashed, sliced, and cooked too. Therefore, it is considered a staple food using different cooking methods such as frying, boiling, smoked, steaming, roasting, or baking. Since there are many banana species, this study focused on Pisang Abu or the scientific name as 'Saba' [Musa 'saba' (Musa acuminata $\times$ Musa balbisiana)]. It is called Pisang Abu Nipah or Pisang Abu or Pisang Nipah among Malaysians, Giant Pisang Kepok, or Kepok by Indonesian, Kluai Hin among Siamese, Chuoi Mat among Vietnamese, and Saba or Cardaba by Filipino (Reginio, Ketnawa \& Ogawa, 2020).

Most studies focused on processed bananas such as juice, puree, flour, and chips (Ranjha, Irfan, Nadeem, \& Mahmood, 2020; Singh et al., 2016). However, based on the previous literature, there is a limited study on the commercial processing of bananas (Elkhalifa, Hassan, \& Zei, 2014). Therefore, this study aims to evaluate frozen banana fritter's nutritional profile and acceptability from the species of 'Saba' [Musa 'saba' (Musa acuminata $\times$ Musa balbisiana)]. This frozen banana can be commercialised and, at the same time, tackle food security since it has a long shelf life when properly stored and used. Nevertheless, it also provides the nutrients needed by the body to grow. Because of that reason, there is a need to preserve bananas for later consumption and to face food security in the long run.

\subsection{Literature Review}

\subsection{The History of Banana and Species}

Banana, a fruit known under the Eumusa section of the genus Moses, originated from the Greek word "Muses" (Singh et al., 2016). The word Moses is also associated with a Roman physician in the first century BC, Antonius Moses. The term 'banana' comes from the Musaceae and Zingiberales family. It was widely used as fruit skin of the genus Moses where it is categorised in these parts as Callimusa, Australimusa Eumusa, and Rhodochlamys.

The word banana existed a long time ago in Malay literature until a Malay proverb says "Bagai goreng pisang panas" which means anything that sells like hotcakes. This Malay proverb displays that banana is a commonly consumed and hot selling fruit among Malay ethnic especially. Apart from that, the other ethnicities like Chinese and Indian or others also prefer to eat a banana as their most appealing daily fruit. It is a trendy street snack in many parts of Southeast Asia, mainly in Malaysia, as it can be sold briskly when it is hotly deep-fried. Hence, banana fruit should be preserved to avoid becoming extinct as it is a responsibility shared by the whole ethnics.

\subsection{The Usage of Banana}

The indigenous germplasm cultivated banana was located at the Malaysian Agricultural Research and Development Institute (MARDI). Uniquely, bananas are considered an exceptional crop due to the usage of their whole plant (Kennedy, 2009). Banana is a significant food source for humans (Sarma, Govila, \& Yadav, 2020) and animals (Cronauer \& Krikorian, 2012). Besides the creamy texture, soft and sweet, everything from the banana and its plant can be utilized (Mohapatra, Mishra \& Sutar, 2010). Banana can be eaten as it is when ripe, can be mashed, and also can be used in many types of cooking such as cook, boil, steam, deep-fried, and bake traditional food. Banana steam is normally used to cook Kerabu Umbut Pisang, Kari Batang Pisang, and the unripe banana is used to cook Gulai Pisang Putik that popular in Northern part of Malaysia - in Kedah, Penang, and Perlis. Meanwhile, the banana skin can be used as fertilizers for other plants, and the banana flower can be used in soup and Kerabu Jantung Pisang. Furthermore, banana leaves are commonly used to wrap food. The banana leaves give a unique aroma to the food, especially Nasi Lemak (a rich and creamy dish in Malay Culture). The Malays traditional food produced from different parts of the banana plants is summarised in Table 2.

Table 2 The Malay traditional dishes produced from banana

\begin{tabular}{ll}
\hline Banana Parts & Malay Traditional Dishes \\
\hline Inner part and Stem & Kerabu Umbut Pisang, Gulai Batang Pisang \\
Unripe banana & Gulai Pisang Putik, Pisang Rebus, Kerepek Pisang \\
Ripe banana & Pisang Goreng, Cucur Kodok, Bubur Pisang, Pengat Pisang, Kek \\
& Pisang, Pulut Dakap, Kuih Talam Pisang, Pulut Pisang, Pek Nga \\
& Pisang. \\
Banana flower & Kerabu Jantung Pisang, Soup \\
\hline
\end{tabular}




\subsection{Nutritive Value of Banana benefits}

There is no doubt that banana is a portion of nutritional food as The World Health Organization (WHO) recommends people to consume at least $400 \mathrm{~g}$ of fruits per day (Who \& Consultation, 2003). Each banana contains Vitamin C, A, carbohydrates, protein, and a considerable amount of potassium (Ferreira \& Freitas, 2019). The carbohydrates in the fruit function as helper enzymes in the metabolic processing of fats and proteins. Therefore, banana is considered a very nutritious fruit that consists of water $(75 \%)$, protein (1.3\%), and fats $(0.6 \%)$. Besides, it also contains bioactive compounds, namely phytosterols, carotenoids, phenolics, and biogenic amines, typically required for human well-being (Singh et al., 2016). These compounds consist of antioxidant activities that can protect oxidative stresses. Thus, banana helps decrease blood pressure, promotes red cell production, keeps the chemical balance among bodily fluids, help energy production, as well as provides endurance against stress. In addition, it triggers the chemical reactions of proteins and amino acids in keeping the brain normally function.

\subsection{Acceptability}

Acceptability could be a subjective degree based on hedonics (delight). It may, in turn, is impacted by the tactile properties of the nourishment, past introduction to it and ensuing desires, relevant components, an individual's culture, physiological status (i.e., starvation,thirst and presence/absence of ailment), and numerous other factors. Food acceptability is influenced by numerous variables; which may be related to the person, the nourishment, or the environment in which the food is devoured. The estimation of food acceptance is exceedingly complex and depends on psychometric (scales) and/or behavioural models (food choice models) (Murray \& Baxter, 2003). How much somebody likes a foodstuff ought to be critically calculated in affecting the choice and utilization of foodstuff or eating habits. These critical impacts of buyer's convictions and desires on items discernment have been illustrated for absolutely tangible measurements of nourishment. They have been appeared to have collective effects on behaviour, e.g., utilization (Caballero, Trugo \& Finglas, 2003). The product's color, texture, taste, and flavour is vital for the new product development. For most consumers, foodstuff flavour appears to be the foremost critical acceptability criterion before appearance and texture (Kumar, Singh \& Pathak, 2020; Baixauli et al., 2002). Therefore, this study focus on the hedonics towards frozen Saba banana in terms of texture, colour, taste, flavour, and overall quality.

\subsection{Methodology}

\subsection{Material}

The Saba banana is well-known for its yellow peel colour and dark brown blot, thick and coarse peel. Its pulp is firm with a mild sweet taste (Hapsari \& Dewi, 2016). This fruit stands out compared to other tropical fruits, mainly due to its high consumption and versatility of use (raw, fried, and cooked), besides being considered as low-cost fruit and having high energetic value (rich in starch) (Borgeset al., 2020). Although Pisang Abu/ Saba banana is not very attractive, it is the most favourable banana and can be utilized at all stages of maturity, either raw or cooked, and is used primarily for manufacturing various food products (Doloiras et al., 2018). There are five stages of maturity of Pisang Abu/ Saba/ Kepok. In this study, we used stage 3. Stage 3 indicates that the banana is suitable for the different cooking processes. The taste, sweetness, and texture are worthy. The outer skin is a velvety texture, whereas the flesh is yellow and contained a consumable seed.

\subsection{Preparation}

To freeze the banana, therefore, several steps need to be completed as follows:

1. The Saba banana (Stage 3 of ripening level) was peeled, cut into half, and deep into the batter.

2. It is fried at $185^{\circ} \mathrm{C}$ temperature for 3.5 to 4 minutes until it turns golden brown and the subsequent need to cool down.

3. Pack and freeze the fried banana at $-18^{\circ} \mathrm{C}$ temperature.

\subsection{Acceptability Attributes Test}

Hedonic liking tests are carried out by consumer panels and usually ask questions of overall acceptability and comments about its characteristics, which consumers like or dislike. After the frozen Saba Crispy was made, therefore, it is ready to be tested by consumers. The frozen Saba Crispy was cut into smaller pieces and was tested by the consumers. The convenient sampling has opted for this study. The participants were recruited based on their voluntarism in Arau, Perlis. The acceptability attributes for the assessment were then clarified. Overall, only 30 consumers have participated in a pilot study. The chosen participants are similar to the consumers who consumed the product, as suggested by Watts, Ylimaki, Jeffery, and Elias (1989). Then, the assessment for the acceptability attributes such as texture, quality, taste, colour, and flavour was distributed. The 5-point Likert scales were used; $1=$ dislike extremely, 2=dislike slightly, 3=neutral, $4=$ like slightly, and $5=$ like extremely (Watts et al., 1989). All these attributes were analyzed by using descriptive analysis.

\subsection{Results and Findings}

\subsection{Nutritive Analysis}


The result of the nutritional profile of Saba banana and the method used is presented in table 3. The calorie of frozen Saba Crispy is 246 $\mathrm{kcal}$ per $100 \mathrm{~g}$ which is higher than the raw Saba banana that is only $148.8 \mathrm{~g}$. The total carbohydrates for frozen Saba Crispy are $39.6 \mathrm{~g}$ for every $100 \mathrm{~g}$, which is slightly higher than $4.36 \mathrm{~g}$ than raw Saba banana $(35.24 \mathrm{~g})$. However, the fat of frozen banana is higher, which 8.8 as compared to raw Saba banana that is only 0.08 . Based on the result, the frozen banana contains more calories and fat. The oil was absorbed during the deep-frying process, increasing the fat content (Pandey, Ravi \& Chauhan, 2020).

\begin{tabular}{|c|c|c|c|c|}
\hline Test Parameter & Unit & Method Usec & $\begin{array}{l}\text { Frozen } \\
\text { result } P \epsilon\end{array}$ & $\begin{array}{l}\text { Raw Sal } \\
\text { per } 100 \mathrm{c}\end{array}$ \\
\hline Calorie/energy & Kcal & $\begin{array}{l}\text { Method of } \\
\text { for Nutrition L } \\
\text { Chapter } 1,1 \leqslant\end{array}$ & 246 & 148.8 \\
\hline Protein & g & $\begin{array}{l}\text { Association C } \\
\text { Agricultural ( } \\
\text { (AOAC 976.C }\end{array}$ & 2.1 & 1.78 \\
\hline Total carbohydr' & $g$ & $\begin{array}{l}\text { Method of } \\
\text { for Nutrition L } \\
\text { Chapter } 1,1 \leqslant\end{array}$ & 39.6 & 35.24 \\
\hline Total fat & $g$ & $\begin{array}{l}\text { The in-house } \\
\text { based on P } \\
\text { Chemical An } \\
\text { Foods, } 8^{\text {th }} \mathrm{Ec}\end{array}$ & 8.8 & 0.08 \\
\hline
\end{tabular}

Table 3 Nutritional Analysis

(Source: Researcher)

The ripe banana is often constrained for the diet of diabetic patients as the portion is limited prescribed due to the high content of carbohydrates and sugars. Yet, under-ripe bananas, either steamed/boiled, contain low glycaemic carbohydrates that may become an acceptable alternative meal for diabetic patients, particularly Type 2 Diabetes (Hermansen et al., 1992). At the ripening stage, carbohydrates in cooking bananas are primarily in starch than sugar, whereas, in dessert bananas, it mainly exists in sugars. Thus, it must be cooked to make the starch available for the digestive organs (Hapsari \&Lestari, 2016). And even though based on the Food Guide Pyramid Malaysia, the Ministry of Health $(\mathrm{MOH})$ recommended consuming at least two fruits daily. However, the total calorie and other nutrition of fruits such as protein and carbohydrates must also be carefully chosen, especially for diabetic patients.

\subsection{The demographic profile}

The result of the demographic profile revealed that female participants recorded at $56.67 \%$ while males at $43.33 \%$. The highest proportion for age is between $26-32$, accounting for $66.67 \%$, and the least is between $18-25$ years old, accounting for $17 \%$ only. The majority of the participants are Malays that is $66.67 \%$, followed by Chinese is $26.67 \%$, and Indian, which accounted for only $6.67 \%$. Finally, the majority of the participants are students that are $66.67 \%$.

Majority of participants (50\%) like incredibly the texture, taste, and flavour of the frozen Banana Crispy. The taste of this product is favoured highly by the participants even though it is frozen. Meanwhile, the texture is a critical quality attribute for the products (Pandey, Ravi \& Chauhan, 2020). At the same time, the participants rated their slightly preference for the colour of the products, which accounted for $66.67 \%$. The golden brown colour of the frozen Saba Crispy is due to the frying method that leads to the browning colour of the product (Pandey, Ravi \& Chauhan, 2020) and the absorption of oil (Baixauli, Salvador, Fiszman \& Calvo, 2002). Therefore, the product's color plays a crucial factor in influencing the consumers' acceptance of fried food. It is related to the food product's acceptability and essential physical characteristics (Baixauli et al., 2002).

\subsection{Conclusion}

Pisang Abu Nipah or Pisang Abu or Pisang Nipah, Giant Pisang Kepok, or Kepok or the scientific name as Saba banana is cultivars from ABB M. balbisiana and M. acuminata wild species. Regardless of the name given, this fruit existed a long time ago, and it is also one of the fruits from Paradise mentioned in the Holy Quran. Due to its high nutritional value, it is recommended that all ages be consumed as it is or cooked, such as frying until it turns to the golden brown colour, subject to their preferences. To prolong the shelf life, the freezing method was used to overcome the short life span of this banana, where it is stored at $-18^{\circ} \mathrm{C}$. Overall, based on the survey conducted, there is a potential for the frozen Saba Crispy to be commercialized because the consumers accept the end product in terms of texture, taste, flavour, colour, and quality. It's vital to highlight that the preliminary study's small sample size has several limitations in this investigation. As a result, it is proposed that a qualitative method or a quantitative method with a high sample size be used to extend and gather more data. Future studies should include more rigorous data analysis employing a structural equation model. 


\section{Acknowledgements}

The authors of this paper would like to thank all representatives. We also extend our gratitude to all participants for spending time on this study.

\section{Paper Contribution to Related Field of Study}

This paper contributed to enhancing Malay ethnic food, consumer behaviour and one of the methods to preserve food to tackle food security issues.

\section{References}

Baixauli, R., Salvador, A., Fiszman, S. M., \& Calvo, C. (2002). Effect of the addition of cornflour and colourants on the colour of fried, battered squid rings. European Food Research and Technology, 215(6), 457-461.

Borges, C. V., Maraschin, M., Coelho, D. S., Leonel, M., Gomez, H. A. G., Belin, M. A. F, \& Lima, G. P. P. (2020). Nutritional value and antioxidant compounds during the ripening and after domestic cooking of bananas and plantains. Food Research International, 132, 109061.

Caballero, B., Trugo, L. C., \& Finglas, P. M. (2003). Encyclopedia of food sciences and nutrition. Academic.

Cronauer, S. S., \& Krikorian, A. D. (2012). Banana (Musa spp.). YPS Bajaj. Trees I. Biotechnology in Agriculture and Forestry. Springer Science \& Business Media, 233.

Doloiras-Laraño, A. D., Garcia, R. N., Sandoval, C. M. C., Lalusin, A. G., Gueco, L. S., Huelgas, V. C., \& Tecson-Mendoza, E. M. (2018). DNA Fingerprinting and Genetic Diversity Analysis of Philippine Saba and Other Cultivars of Musa balbisiana Colla Using Simple Sequence Repeat Markers. Philippine Journal of Crop Science (P. JCS), 43(2), 1-11.

Elkhalifa, A. E. O., Hassan, A. M., \& Zei, M. E. A. (2014). Analytical quality and acceptability of baked and fried banana chips. Journal of Human Nutrition and Food Science, 2(6), 1052

Ferreira, T. H., \& Freitas, M. L. (2019). Production, physical, chemical and sensory evaluation of dried banana (Musa Cavendish). Emirates Journal of Food and Agriculture.

FAOSTAT (2014). Statistical Database of the Food and Agriculture Organization of the United Nations. http://faostat.fao.org/.

Hapsari, L., \& Lestari, D. A. (2016). Fruit characteristic and nutrient values of four Indonesian banana cultivars (Musa spp.) at different genomic groups. AGRIVITA, Journal of Agricultural Science, 38(3), 303-311.

Hermansen, K., Rasmussen, O., Gregersen, S. \& Larsen, S. (1992). Influence of ripeness of banana on the blood glucose and insulin response in type 2 diabetic subjects. Diabetic Medicine, 9(8), 739- 743

Holy Quran, Al Waqiah 56:29.

Kennedy, J. (2009). Bananas and people in the homeland of genus Musa: not just pretty fruit. Ethnobotany Research and Applications, 7, $179-197$.

Kumar, B., Singh, V. P., \& Pathak, V. (2020). Quality Characteristics of Banana based Milk Smoothies Developed from Milk of Hariana, Sahiwal and Cross Breed Cows. Asian Journal of Dairy \& Food Research, 39(1)

Lassoudière, A. (2007). Bananier et sa culture (le) (p. 383). Versailles CEDEX, France: Editions Quae

Ministry of Health Malaysia. (2010). Malaysia Dietary Guidelines and Malaysian Food Pyramid.

Murray, J. M., \& Baxter, I. A. (2003). Sensory Evaluation Food Acceptability and Sensory Evaluation.

Mohapatra, D., Mishra, S., \& Sutar, N. (2010). Banana and its by-product utilisation: an overview.

Nelson, S. C., Ploetz, R. C., \& Kepler, A. K. (2006). Musa species (banana and plantain). Species profiles for Pacific Island agroforestry, 15(2), 251-259.

Pandey, A. K., Ravi, N., \& Chauhan, O. P. (2020). Quality attributes of vacuum fried fruits and vegetables: a review. Journal of Food Measurement and Characterization, $1-14$

Price, N. S. (1995). The origin and development of banana and plantain cultivation. In Bananas and plantains (pp. 1-13). Springer, Dordrecht.

Ranjha, M. M. A. N., Irfan, S., Nadeem, M., \& Mahmood, S. (2020). A Comprehensive Review on Nutritional Value, Medicinal Uses, and Processing of Banana. Food Reviews International, 1-27.

Reginio, F. C., Ketnawa, S., \& Ogawa, Y. (2020). In vitro examination of starch digestibility of Saba banana [Musa 'saba'(Musa acuminatax Musa balbisiana)]: impact of maturity and physical properties of digesta. Scientific Reports, 10(1), 1-10.

Sarma, U., Govila, V. K., \& Yadav, A. (2020). The traditional and therapeutic use of banana and its plant-based delicacies in ethnic Assamese cuisine and religious rituals from Northeast India. Journal of Ethnic Foods, 7(1), 1-7.

Singh, B., Singh, J. P., Kaur, A., \& Singh, N. (2016). Bioactive compounds in banana and their associated health benefits-A review. Food Chemistry, $206,1-11$.

Watts, B. M., Ylimaki, G. L., Jeffery, L. E., \& Elias, L. G. (1989). Basic sensory methods for food evaluation. IDRC, Ottawa, ON, CA 
Din, N., et.al. / AcE-Bs2021, $9^{\text {th }}$ Asian Conference on Environment-Behaviour Studies, Perdana Kota Bharu, Kelantan, Malaysia, 28-29 Jul 2021, E-BPJ, 6(17), Aug 2021 (pp.199-204)

Who, J., \& Consultation, F. E. (2003). Diet, nutrition and the prevention of chronic diseases. World Health Organ Tech Rep Ser, 916(i-viii). 